\title{
Development and validation of UV spectrophotometric method for quantitative estimation of nitroglycerin in pharmaceutical dosage form
}

\author{
*Rajia Sultana Nijhu1, Dewan Taslima Akhter1, Yeakuty Marzan Jhanker² \\ ${ }^{1}$ Department of Pharmacy, Stamford University Bangladesh, 51, Siddeswari Road, Dhaka-1217, Bangladesh \\ ${ }^{2}$ Department of Pharmacy, The University of Asia Pacific, Dhanmondi, Dhaka-1209, Bangladesh
}

\begin{abstract}
A new, simple, specific, sensitive, rapid and economical procedure has been developed for determination of Nitroglycerin in its dosage form. The objective of this validation of an analytical procedure is to demonstrate that the drug Nitroglycerin is suitable for its intended purpose. The analytical method development recommends the quality, purity and specificity of the drug Nitroglycerin tablet form during the manufacturing process and hence the standard of the drug may not vary, which produce the desirable therapeutic effect. The method is based on the ultraviolet absorbance maxima of the above drug at $210 \mathrm{~nm}$. The drug obeyed Beer's law in the concentration range of $15 \mu \mathrm{g} / \mathrm{ml}$ in methanol. The proposed methods were successfully applied for the determination of drug in commercial tablet preparations. The results of the analysis have been validated statistically and by recovery studies.
\end{abstract}

Key Words: Nitroglycerin, ultraviolet spectroscopy, analysis, dosage form, validation.

\section{INTRODUCTION}

The scope of developing and validating analytical method is to ensure a suitable method for a particular analyte more specific, accurate and precise the main objective for that is to improve the condition and parameter, which should be followed in the development and validation Nitroglycerin (NTG) has been the foremost anti-ischemic agent used in clinical medicine for more than a century. NTG is a potent vasodilator of veins, arterial conductance vessels, and collaterals that has minimal effects on arteriolar tone. At the cellular level, NTG is biotransformed by a still unknown enzymatic process in endothelial cells, smooth muscle, and to some extent platelets, causing it to release the vasodilator and anti-aggregatory principle nitric oxide. The two major drawbacks of

*Corresponding Author:

Rajia Sultana Nijhu, Teaching Assistant

Department of Pharmacy, Stamford University Bangladesh

51, Siddeswari Road, Dhaka-1217, Bangladesh

E-mail: razia.sultana_nizhu@yahoo.com

Phone: +88 01712192269 nitrate therapy that have been shown to be important are the rapid development of nitrate tolerance and endothelial dysfunction within several days of prolonged NTG treatment (Gori et al., 2001; Azevedo et al., 2001). There is a growing body of evidence that both NTG-induced side effects may be at least in part secondary to NTG-stimulated production of oxygen-derived free radicals within vascular tissue (Schulz et al., 2002; Gori et al., 2001). Increased oxidative stress correlates positively with increased cardiovascular event rates, (Heitzer et al., 2001) which may, at least in part, explain why NTGtherapy either failed to improve or worsened the prognosis in patients with acute myocardial infarction and chronic ischemic heart disease, respectively. The mechanisms by which NTG and NO inhibit platelet aggregation include the stimulation of the soluble guanylyl cyclase, leading to enhanced formation of the second messenger cGMP, but may also involve cGMP-independent mechanisms (Sogo et al., 2000). 
Table 1: Data for System Precision Test

\begin{tabular}{cccc}
\hline $\begin{array}{c}\text { Sample } \\
\text { Concentra- } \\
\text { tion }(\mu \mathrm{g} / \mathrm{ml})\end{array}$ & $\begin{array}{c}\text { No. of } \\
\text { Measure- } \\
\text { ment }\end{array}$ & $\begin{array}{c}\text { Absor- } \\
\text { bance }\end{array}$ & $\begin{array}{c}\text { Relative Standard } \\
\text { Deviation }\end{array}$ \\
\hline & 01 & 0.605 & \\
& 02 & 0.604 & \\
$15.17 \mu \mathrm{g} / \mathrm{ml}$ & 03 & 0.599 & $0.740 \%$ \\
& 04 & 0.609 & \\
& 05 & 0.612 & \\
& 06 & 0.605 & \\
\hline
\end{tabular}

Oral drug delivery method is the most widely utilized routes for administration among all alternatives that have been explored for systemic delivery of drug via various pharmaceutical products of different dosage forms. Popularity of the route may be ease of administration as well as traditional belief that by oral administration the drug is due to the well absorbed into the food stuff ingested daily (Allen et al., 2005). Validation of an analytical procedure is performed in order to demonstrate that the procedure is suitable for its intended use and to show that the result(s) generated by a particular analytical procedure are reliable and accurate. Analytical methods development of validation plays important roles in the discovery, development and manufacture of Pharmaceutical. The official test methods that result from those processes are used by quality control laboratories to ensure the identity, purity, potency and performance of drug product. Method validation is defined as the process of method proving through scientific studies that an analytical methods is acceptable for it intended in recent years, a great deal of efforts has been devoted to the harmonization of Pharmaceutical use. UV Spectroscopy method is one of the instrumental analytical methods that are widely used in pharmaceutical industries for the assay of pharmaceutical products, because it is simple, easy, less time consuming and an economical method (Fatema et al., 2010). Literature survey revealed that various analytical methods such as TLC, liquid chromatography, fluorimetric method, are used for estimation of Nitroglycerin (Takashi et al., 2006; Price and Price, 2008). No simple UV-spectrophotometric method has been reported for estimation of Nitroglycerin tablet dosage form. Hence, an attempt has been made to develop new spectrophotometric method for its estimation in pharmaceutical tablet dosage form with good accuracy, simplicity and precision. An UV method for the assay of Nitroglycerin in Tablet has been validated based on the below test procedure. Examined validation characteristics include i) System precision/System Suitability; ii) Method Precision; iii) Accuracy; iv) Specificity; v) Linearity and vi) Robustness.

The purpose of this analytical method validation is to demonstrate that this method is suitable for the intended purpose and capable of giving reproducible results.

\section{MATERIALS \& METHODS}

Chemicals and Reagents: Reference standard of Nitroglycerin was kind gift from Aristopharma Ltd., Bangladesh. All other ingredients used were of analytical grade. Instruments: UV-Visible spectrophotometer (Shimadzu UV-1601 PC and UV-1700), Electric balance (Type AUY 120 Shimadzu).

Preparation of standard solution at specific concentration and scanning wavelength at specified media

$75 \mu \mathrm{g} / \mathrm{ml}$ of stock solution was prepared by dissolving $7.5 \mathrm{mg}$ of Standard Diluted Nitroglycerin in $100 \mathrm{ml}$ methanol. $15 \mu \mathrm{g} / \mathrm{ml}$ standard solution was prepared by dilution from stock solution. The wavelength of maximum emission $(\lambda \max )$ of Nitroglycerin in specified media was found $210 \mathrm{~nm}$

Table 2: Data for Method Precision Test

\begin{tabular}{ccccc}
\hline Sample No. & $\begin{array}{c}\text { Sample Weight } \\
(\mathbf{m g})\end{array}$ & Assay $(\mathbf{m g})$ & \% of Label Claim & $\begin{array}{c}\text { Relative Standard } \\
\text { Deviation }\end{array}$ \\
\hline 01 & 484.80 & 2.75 & 105.76 \\
02 & 483.90 & 2.74 & 105.38 & \\
03 & 483.69 & 2.75 & 105.76 & $0.291 \%$ \\
04 & 484.60 & 2.76 & 106.15 & \\
05 & 484.70 & 2.74 & 105.38 \\
06 & 484.87 & 2.74 & 105.42 & \\
\hline
\end{tabular}




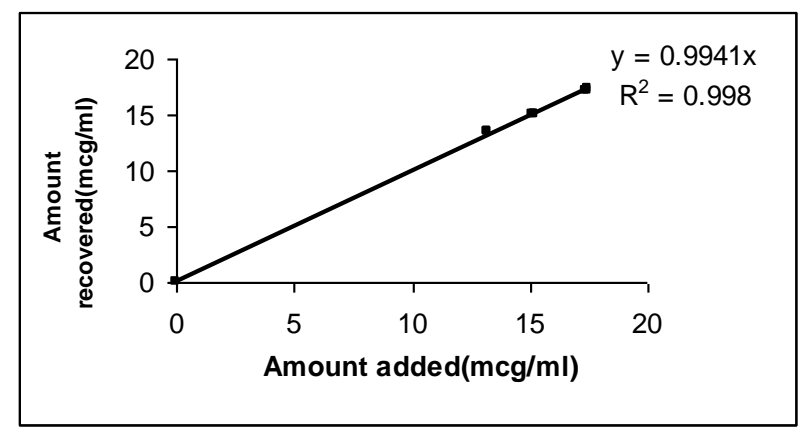

Figure 1: Graphical representation of Accuracy

by scanning them over the UV range of $190 \mathrm{~nm}$ to $400 \mathrm{~nm}$.

Preparation of sample solution at specific concentration and scanning wavelength at specified media

20 tablets of marketed brands of Nitroglycerin were weighed separately. Average weight of them was determined. Powder of tablets equivalent to about $7.5 \mathrm{mg}$ of Nitroglycerin were weighed and taken in a $100 \mathrm{ml}$ volumetric flask. $70 \mathrm{ml}$ of methanol was added and mechanical shaking was performed for about 25 minutes to dissolve. It was filtered through Whitman filter paper no.41 and made $100 \mathrm{ml}$ with methanol. Further dilution was carried out by methanol. The wavelength of maximum emission ( $\lambda \max )$ of Nitroglycerin in specified media was found $210 \mathrm{~nm}$ by scanning them over the UV range of $190 \mathrm{~nm}$ to $400 \mathrm{~nm}$.

\section{System precision/System Suitability}

System suitability testing is an integral part of many analytical procedures. System suitability test parameters depend on the type of procedure being validated. System precision is determined by measuring the absorbance of standard solution containing $100 \%$ working concentration for six times and calculates the \%RSD. The \%RSD should be less than $2.0 \%$. The relative standard deviation of six replicate measurement of standard solution was found to be $0.740 \%$ (limit NMT 2.0\%), which indicates that the system is precise to analyze the sample.

\section{Method Precision}

Method precision was established by analyzing six separate samples at $100 \%$ of the working concentration. Percent of result was calculated

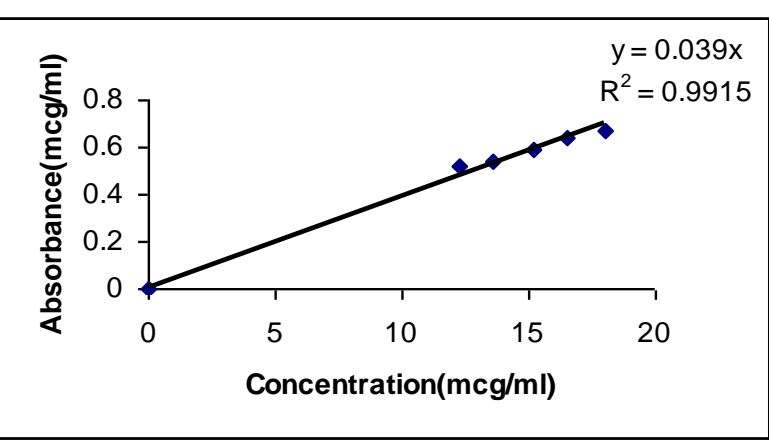

Figure 2: Graphical representation of Linearity

against claimed label. The \%RSD of assay result of six separate samples from a single batch was found to be $0.291 \%$ (limit NMT $2.0 \%$ ) which indicates that the method is precise to analyze the tablet.

\section{Accuracy}

Accuracy was established by analyzing nine sample solutions of Nitroglycerin at $80 \%, 100 \%$ and $120 \%$ of the working concentration (Three replicates for each concentration) into a placebo mixture and by calculating the percent recovery of active ingredient from the placebo solution. The percent recovery at each level should be within $97.0 \%$ to $103.0 \%$. A linear curve was prepared by plotting amount added Vs amount recovered correlation co-efficient. The percent recovery was calculated for nine determinations and found to be within limit. A graphical representation between amount added Vs amount recovered also shows linearity. Thus it has been concluded that the method is accurate to analyze the Tablet.

\section{Specificity \\ Identification}

The UV absorption spectrum of the sample preparation for assay is concordant with the reference spectrum of standard sample from assay preparation.

\section{Placebo Interference}

Placebo solution was prepared in the same manner as standard and sample preparation. No interference of placebo was found.

\section{Linearity}

Five different standard solutions were prepared covering a concentration of $80 \%$ to $120 \%$ of the working concentration of Nitroglycerin and all 
Table 3: Data for Accuracy Test

\begin{tabular}{ccccc}
\hline $\begin{array}{c}\text { Concen- } \\
\text { tration } \\
\text { level }\end{array}$ & $\begin{array}{c}\text { Sample } \\
\text { No. }\end{array}$ & $\begin{array}{c}\text { Amount } \\
\text { added } \\
(\mu \mathrm{g} / \mathrm{ml})\end{array}$ & $\begin{array}{c}\text { Amount } \\
\text { Recovered } \\
(\mu \mathrm{g} / \mathrm{ml})\end{array}$ & $\begin{array}{c}\text { \% Reco- } \\
\text { very }\end{array}$ \\
\hline \multirow{2}{*}{$80 \%$} & 1 & 13.21 & 13.42 & 101.58 \\
& 2 & 13.22 & 13.44 & 101.66 \\
& 3 & 13.24 & 13.52 & 102.11 \\
\hline \multirow{2}{*}{$100 \%$} & 1 & 15.17 & 14.99 & 98.81 \\
& 2 & 15.24 & 14.94 & 98.03 \\
& 3 & 15.09 & 15.04 & 99.67 \\
\hline \multirow{2}{*}{$120 \%$} & 1 & 17.43 & 17.27 & 99.08 \\
& 2 & 17.35 & 17.04 & 98.21 \\
& 3 & 17.47 & 17.14 & 98.11 \\
\hline
\end{tabular}

absorbance were recorded. A linear curve was prepared by plotting actual concentration $(\mu \mathrm{g} / \mathrm{ml}$ or ppm) Vs absorbance and correlation co-efficient was calculated. The results obtained correlate with the concentrations resulting in the following calibration curve. The correlation co-efficient found 0.9915, which is within the limit (limit: NLT 0.990). Thus the graph confirms the linearity of the method in the range of $80 \%$ to $120 \%$.

\section{Robustness}

Robustness of this method was determined by analyzing the Nitroglycerin Tablet in different equipment in different day and by different analyst. From the above-mentioned data it observed that the method is robust enough to analyse Nitroglycerin Tablet.

\section{RESULTS AND DISCUSSION}

The analytical method development and validation for the drug Nitroglycerin was done, which shows the best elution of the peak. The specificity test studies shows that the analyte chromatographic peak is not attributable to more than one component. The linearity calibration curve shows linear response over the range of concentration used. The precision data shows that the reproducibility of the

Table 4: Data for Linearity Test

\begin{tabular}{cccc}
\hline $\begin{array}{c}\text { percent } \\
\text { Concentration }\end{array}$ & $\begin{array}{c}\text { Concentration } \\
(\boldsymbol{\mu g} / \mathbf{m l} \text { or } \mathbf{~ p p m})\end{array}$ & $\begin{array}{c}\text { Absorb- } \\
\text { ance }\end{array}$ & $\begin{array}{c}\text { Correlation } \\
\text { Co-efficient }\end{array}$ \\
\hline 80 & 12.25 & 0.518 & \\
90 & 13.58 & 0.536 & 0.9915 \\
100 & 15.17 & 0.594 & \\
110 & 16.54 & 0.639 & \\
120 & 18.06 & 0.674 & \\
\hline
\end{tabular}

Table 5: Data for Robustness Test

\begin{tabular}{|c|c|c|}
\hline $\begin{array}{l}\text { Sl. } \\
\text { No. }\end{array}$ & Variable Parameters & $\begin{array}{c}\text { Assay results } \\
(\%)\end{array}$ \\
\hline \multirow[b]{2}{*}{1} & Analyst-1 & 102.35 \\
\hline & Analyst-2 & 100.18 \\
\hline \multirow{4}{*}{2} & Equipment-1 & \\
\hline & $\begin{array}{l}\text { (UV Spectrophotometer } \\
\text { Model-UV-1700) }\end{array}$ & 101.00 \\
\hline & Equipment-2 & \\
\hline & $\begin{array}{l}\text { (UV Spectrophotometer } \\
\text { Model-UV-1601 PC) }\end{array}$ & 101.00 \\
\hline \multirow{2}{*}{3} & Day-1 & 100.78 \\
\hline & Day-2 & 101.54 \\
\hline
\end{tabular}

assay procedure was satisfactory. The accuracy of the method was determined by recovery studies. The recovery studies were carried out of the percentage recovery was calculated. The Robustness studies show that there were no marked changes in the chromatogram. The Ruggedness of the method was determined for the same sample under different laboratory, different analysis and using operational and environmental conditions; the degree of reproducibility will shows results within their limits. Further there was no interference due to excipients. The system suitability studies were also carried out to determine peak asymmetry.

\section{CONCLUSION}

From the above data it was observed that all validation parameters (like system suitability, method precision, accuracy, specificity, linearity, robustness) meet the predetermined acceptance criteria. Thus it has been concluded that the method is validated for the analysis of assay of Nitroglycerin in Tablet dosage form.

\section{REFERENCE}

Allen, L.V., Popovich, N.G., Ansel, H.C. (2005). Ansel's Pharmaceutical Dosage Forms and Drug Delivery Systems. (8th ed., pp. 260-275). Lippincott Williams \& Wilkins.

Azevedo, E.R., Schofield, A.M., Kelly, S., et al. (2001). Nitroglycerin withdrawal increases endotheliumdependent vasomotor response to acetylcholine. J Am Coll Cardiol.; 37: 505-509.

Fatema, K., Rahman, Z., Biswas, S.K., Akter, S. (2010). Development of UV Spectroscopic Method for 
Mefopam and Escitalopram as INN Drugs in Tablet Dosage Form. Stamford j. pharm. sci. 3(1): 4-10.

Gori, T., Burstein, J.M., Ahmed, S., et al. (2001). Folic acid prevents nitroglycerin-induced nitric oxide synthase dysfunction and nitrate tolerance: a human in vivo study. Circulation.; 104: 1119-1123.

Gori, T., Mak, S.S., Kelly, S., et al. (2001). Evidence supporting abnormalities in nitric oxide synthase function induced by nitroglycerin in humans. J Am Coll Cardiol.; 38: 1096-101.

Heitzer, T., Schlinzig, T., Krohn, K., et al. (2001). Endothelial dysfunction, oxidative stress, and risk of cardiovascular events in patients with coronary artery disease. Circulation.; 104: 2673-2678.

Price, J.W., Price, J.R. (2008). Accuracy and precision of metered doses of nitroglycerin lingual spray; American journal of health-system pharmacy. 65(16): 1556-1559.
Schulz, E., Tsilimingas, N., Rinze, R., et al. (2002). Functional and biochemical analysis of endothelial (dys) function and NO/cGMP signaling in human blood vessels with and without nitroglycerin pretreatment. Circulation.; 105: 1170-1175.

Sogo, N., Magid, K.S., Shaw, C.A., et al. (2000). Inhibition of human platelet aggregation by nitric oxide donor drugs: relative contribution of cGMP-independent mechanisms. Biochem Biophys Res Commun.; 279: 412419.

Takashi, M., Pei-Suen, T., Sun-Mi, F., Ho-Leung, F. (2006). Simultaneous determination of nitroglycerin and dinitrate metabolites in metabolism studies using liquid chromatography-mass spectrometry with electrospray ionization. Journal of Chromatography B. 835(1-2): 2126. 